\title{
THE FIRST REPORT ON ALTERNATE BEARING OF BARBERRY (BERBERIS VULGARIS L.): CHANGE IN TOTAL CARBOHYDRATE AND PHENOLIC CONTENTS
}

\author{
Mehdi KHAYYAT*, Zeinab AREFNEZHAD, Mohammad Hasan Sayyari ZAHAN, \\ Gholamreza ZAMANI \\ Department of Horticultural Science, University of Birjand \\ 330 Birjand, Iran
}

Received: December 2017; Accepted: Mai 2018

\begin{abstract}
Barberry (Berberis vulgaris L.) fruit is an important source of anthocyanins and is used for consumption and in medicine. However, fruit production of barberry is not regular. Two experiments in four locations were conducted on this plant to explore if it is alternate bearer and also to investigate carbohydrates and phenolics contents in leaves and shoots during growth season. Evaluation of barberry shrubs in three different location showed strong alternate bearing. The value of leaf number to berry number ratio was small. A correlation was found between tree age and alternate bearing index (ABI), because elder shrubs exhibited more ABI. Total carbohydrates and phenolics contents in vegetative organs showed an increase during the fruit setting stage, except for the carbohydrates in shoots. The highest value of carbohydrates was observed 10 days after leaf appearance and then decrease. ON bearing shrubs showed the highest value of total carbohydrates content in leaves during fruit setting stage, after which it decreased. However, OFF bearing shrubs indicated a reducing trend in this variable. In both bearing statuses (ON and OFF trees), total carbohydrates decreased with season progression. It is concluded that this plant is strongly alternate bearer and this characteristic may be related to carbohydrates and phenolics changes in leaf and shoot organs.
\end{abstract}

Key word: alternate bearing index, biennial bearing, post ripening foliation period

\section{INTRODUCTION}

Seedless barberry (Berberis vulgaris var. asperma $\mathrm{L}$.) has received much attention around the world because of high medicinal properties. Barbery fruits are an important source of anthocyanins (Rezvani Moghaddam et al. 2013), pigments, and other valuable compounds. Barberry plants are cultivated as domestic ones in South Khorasan province of Iran. Fruit production is not regular, with high in one year followed by low yielding in the next year. This alternate bearing has a negative economic result in some years. This character is synchronous throughout South Khorasan so that most farmers have no income.
Problems of alternate (or biennial) bearing in fruit trees have been studied extensively in the past. There are a number of reports about alternate bearing in fruit plants, including pistachio (Monselise \& Goldschmidt 1982; Crane \& Nelson 1971; Nzima et al. 1997a, b, 1999), pecan (Sparks 1975, Gemoets et al. 1976), olive (Goldschmidt \& Golomb 1982; Mert et al. 2013), and apple (Williams and Edgerton., 1974). Alternate bearing results from genetic characteristics, growth conditions, crop load, and influence of other specific annual variables concerning carbohydrate storage and mobilization. Two theories, carbohydrate theory (CT) and phytohormone theory (PT), are developed to explain the mechanism of alternate bearing (Barnett \& Mielke 1981). Wood 
(1991) stated that flowering and subsequent cropping of pecan trees are controlled by dormant season carbohydrate pools. There are many reports showing that carbohydrate reserves in stems of temperate deciduous trees decrease during spring growth flush, reach a minimum during early summer, and subsequently increase to a maximum during late summer and early autumn, before the onset of dormancy (Kozlowski \& Keller 1966; Kramer \& Kozlowski 1979; Oliveira \& Priestly 1988; Kozlowski 1992). Nzima et al. (1997a) stated an increase in starch and soluble sugar concentrations in a currentseason and in 1-year-old stems immediately following bloom and then a marked decline in fruiting trees at the kernel development stage.

Fahmi (1958) showed changes in carbohydrate components in leaves of olive trees during bearing $(\mathrm{ON})$ - and non-bearing (OFF)-years and stated that sugars and starch are much higher at the beginning of a bearing than of a non-bearing years. Poli (1979) found that a delicate balance between vegetative and reproductive growth is needed for regular bearing in olive. Goldschmidt and Golomb (1982) observed that starch and soluble sugar concentrations are higher in OFF than ON trees of citrus, and the majority of this reserve pool would be used for next year's crop.

Phenolic and flavonoid compounds are also mentioned to be related to alternate bearing of fruit trees. Mert et al. (2013) found significant differences in phenolic compounds between ON and OFF trees of olive. They indicated a relationship between alternate bearing of olive trees and phenolic contents in shoots. Moreover, there are some reports indicating fluctuation of phenolic compounds in olive leaves during growth season (Ryan et al. 2003; Ercan \& Özkaya 2008). There is an extensive body of literature related to alternate bearing of olive, showing that some of the produced signals are intercepted by leaves in response to environmental conditions to create chemical changes. Phenolic and flavonoid compounds are involved in the arrest of flower bud formation during the physiological initiation periods (Lavee 1989; Akillioglu 1995; Ryan et al. 2002, 2003).

The basic physiology of alternate bearing in barberry is unknown. The general carbohydrate theory says that fruit setting and production is proportional to the size of carbohydrate pool at dormant stage and also there is a relation between pool size and late-season net photo assimilation capacity of the tree's canopy.

The main aims of this study were to evaluate alternate bearing index for barberry under different conditions to show if this plant is alternate bearer or not and to study the carbohydrate and phenolic compounds changes in different organs of this plants during $\mathrm{ON}$ and $\mathrm{OFF}$ statuses.

\section{MATERIAL AND METHODS}

\section{Subject and method of study}

Experiments were conducted on seedless barberry (B. vulgaris L. var. asperma) shrubs at differently located commercial orchards (Table 1) in Birjand suburban, Iran, in 2012-2017 growing seasons. Shrubs used in the experiment were propagated with method of sucker. Study was performed on uniform shrubs (150 $\pm 20 \mathrm{~cm}$ in height), planted at spacing of 3-4 $\mathrm{m} \times 2-3 \mathrm{~m}$ depended on the location, in both $\mathrm{ON}$ and $\mathrm{OFF}$ statuses. The selected shrubs were pruned, irrigated, fertilized, and manured according to the conventional orchard management. The soil was deep and loamy. Two experiments were performed. The goal of the first experiment, conducted in three locations, Amirabad, Sarbishe, and Zohan, in years 2012-2017, was to find out whether barberry plants are biennial bearers.

Table 1. Characteristics of growth conditions in the locations where experiments were carried out

\begin{tabular}{lcccccc}
\hline \multirow{2}{*}{ Location } & $\begin{array}{c}\text { Altitude* } \\
n\end{array}$ & \multicolumn{3}{c}{ Mean temperature $\left({ }^{\circ} \mathrm{C}\right)^{* *}$} & \multicolumn{2}{c}{ Soil } \\
\cline { 3 - 7 } & $(\mathrm{m})$ & yearly & day & night & $\mathrm{pH}$ & $\mathrm{EC}\left(\mathrm{dS} \cdot \mathrm{m}^{-1}\right)$ \\
\hline Marak & 1648 & 23.34 & 31.97 & 14.69 & 7.50 & 5.70 \\
Amirabad & 1480 & 25.01 & 30.54 & 22.82 & 7.80 & 6.72 \\
Sarbishe & 1839 & 20.18 & 24.39 & 18.45 & 7.15 & 3.47 \\
Zohan & 1459 & 21.73 & 27.43 & 21.74 & 7.85 & 4.83 \\
\hline
\end{tabular}

*above the sea level, ** data from logger and the nearest weather station 
Data were collected from trees aged $\leq 20$ to $\geq 50$ years. Three randomized shoots on each shrub were selected for evaluation. The number of leaves in each node, berry number in each inflorescence, and alternate bearing index $(\mathrm{ABI})$ were calculated. Final fruit yield of ON and OFF shrubs harvested independently for each location was evaluated during 6 successive years, and the data collected were used as follow for calculating ABI based on Hoblyn et al. (1936):

$$
\begin{gathered}
\mathrm{I}=\frac{1}{n-1}\left(\frac{|\mathrm{a} 2-\mathrm{a} 1|}{(\mathrm{a} 2+\mathrm{a} 1)}+\frac{|\mathrm{a} 3-\mathrm{a} 2|}{(\mathrm{a} 3+\mathrm{a} 2)}+\cdots \frac{|\mathrm{a}(\mathrm{n})-\mathrm{a}(\mathrm{n}-1)|}{(\mathrm{a}(\mathrm{n})+\mathrm{a}(\mathrm{n}-1)}\right) ; \\
0<\mathrm{I}<1
\end{gathered}
$$

where $\mathrm{n}$ is the number of years and $\mathrm{a} 1, \mathrm{a} 2, \ldots, \mathrm{a}(\mathrm{n}-1)$, $\mathrm{a}(\mathrm{n})$ are the yields of corresponding years. ABI index may vary between 0 (no alternate bearing) and 1 (complete alternate bearing).

Connection of shrub age with ABI value was also evaluated by comparing plants in the following age groups: less than 20, between 21 and 30, between 31 and 40, between 41 and 50, and more than 51 years old. Also the length of post-ripening foliation period (PRFP) was evaluated for this shrub (date of $75 \%$ canopy defoliation minus date of fruit ripening). All assessments were done under orchard conditions. In the second experiment, two locations, Marak and Amirabad, were selected. This experiment was performed in one year, so two locations were selected for more assurance of data. Data were collected from plants aged 15 to 20 years. Carbohydrates and phenolics contents were assessed in shoots and leaves. Because there were no one-year-old shoots in OFF shrubs (during the harvest, fruits are removed from shrubs with oneyear-old branches), shoot samples were prepared from current-season growth. From ON shrubs, shoot samplings were taken from one-year-old branches. Samplings for assessment of total carbohydrates and phenolics contents were taken in April (10 days after leaf appearance), May (fruit setting, 23 days after full bloom), and September (fruit's color change, 125 days after full bloom). All samples were transported to the laboratory in sealed plastic bags for quick evaluation. Total carbohydrates were evaluated by anthrone-sulfuric acid assay using method of Irigoyen et al. (1992), and the absorption was determined by spectrophotometer (SHIMADZU AA-670, Japan) at $625 \mathrm{~nm}$. Total phenolics were evaluated based on Folin-Ciocalteu method (Singleton \& Rossi 1965), and the absorbance was measured at $725 \mathrm{~nm}$ using a spectrophotometer.

\section{Experimental design and data analysis}

The first experiment was performed based on complete randomized block design on 45 uniform shrubs (15 in each location), 3 replications with 5 shrubs in each. The second experiment was conducted as factorial based on complete randomized design, on 100 uniform shrubs including 5 replications with 10 shrubs (ON or OFF) in each (50 shrubs for each location). Different factors including locations, sampling time, and shrub bearing (ON and OFF) were used in this experiment. Statistical analysis of data was performed using analysis of variance (ANOVA) to determine statistically different values, and the means were compared using a least significant difference (LSD) test $\left({ }^{*} \mathrm{p}<0.05\right)$ for both experiments. All statistical analyses were performed using SAS version 9.1. Data were presented as means \pm standard error (SE).

\section{RESULTS AND DISCUSSION}

Experiment 1. Primary evaluation of plants grown under different locations indicated that barberry is strongly alternate bearer or biennial bearer. Alternate bearing index in all locations was higher than 0.60 , showing significant differences among them (Table 2). Similar results were reported for olive (Morettini 1950) and pistachio (Crane \& Nelson 1971). It is believed that plants whose fruit ripens early in the growing season or plants having a longer PRFP and vegetative growth will accumulate a larger pool of assimilates and thus show lower ABI compared with those ripen late in the season (Nzima et al. 1997a). Fruit ripening of barberry is late in season, and thus, a short PRFP was observed in two of the experimental sites (Table 2). There was a linear correlation between PRFP and ABI in different locations $\left(\mathrm{R}^{2}=0.993\right)$ (data not shown), which shows the influence of the length of PRFP on photo assimilation of barberry shrubs. It seems that this plant needs more time after harvesting to revise their storage pools and accumulate more carbohydrates for future activities. 
Table 2. Characteristic of fruit yielding and morphology of shrubs in different locations presented as means from years (2011-2016)

\begin{tabular}{lccc}
\hline \multirow{2}{*}{ Trait } & \multicolumn{3}{c}{ Location } \\
\cline { 2 - 4 } & Amirabad & Zohan & Sarbishe \\
\hline ABI* & $0.63 \mathrm{~b} \pm 0.0011$ & $0.71 \mathrm{a} \pm 0.0186$ & $0.70 \mathrm{a} \pm 0.0139$ \\
PRFP (day**) & $23.5 \mathrm{a} \pm 4.28$ & $6.8 \mathrm{~b} \pm 1.17$ & $7.4 \mathrm{~b} \pm 2.94$ \\
Leaf/ Node & $3.00 \mathrm{~b} \pm 0.11$ & $4.00 \mathrm{a} \pm 0.65$ & $3.00 \mathrm{~b} \pm 0.11$ \\
Berry No./ Inflor. & $26.80 \mathrm{c} \pm 2.94$ & $43.60 \mathrm{a} \pm 4.39$ & $35.10 \mathrm{~b} \pm 3.14$ \\
Leaf/ Berry No. ratio & $1.1 \mathrm{a} \pm 0.01$ & $0.09 \mathrm{~b} \pm 0.01$ & $0.08 \mathrm{~b} \pm 0.03$ \\
\hline
\end{tabular}

$\mathrm{ABI}$ - alternate bearing index, **PRF $\mathrm{P}$ - post-ripening foliation period, $\mathrm{n}=15$ trees in each location, in each row data presented as means $\pm \mathrm{SE}$.

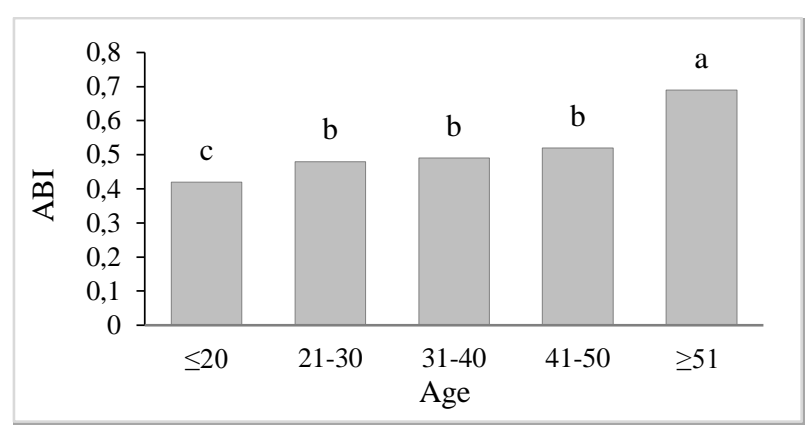

Fig. 1. Effect of plants age in the beginning of experiment on alternate bearing index $(\mathrm{ABI})$ value

Data are means of 6 successive years (2011-2016). Means with the same letter are not significant using LSD test $\left({ }^{*} \mathrm{P}<0.05\right), \mathrm{n}=15$ trees in each location, three replications with 5 trees in each.

Table 3. Single effects of location, sampling date and bearing status on total carbohydrates and phenolics contents in shoots

\begin{tabular}{lcc}
\hline \multirow{2}{*}{ Source } & $\begin{array}{c}\text { Carbohydrates } \\
\left(\mathrm{mg} \cdot \mathrm{g}^{-1} \mathrm{DM}\right)\end{array}$ & $\begin{array}{c}\text { Total phenolics } \\
\left(\mathrm{mg} \text { gallic acid } \cdot \mathrm{g}^{-1}\right. \\
\mathrm{DM})\end{array}$ \\
\cline { 2 - 3 } & \multicolumn{2}{c}{ Location } \\
\hline Amirabad & $13.29 \mathrm{~b} \pm 2.568$ & $63.820 \mathrm{a} \pm 0.160$ \\
Marak & $21.16 \mathrm{a} \pm 5.038$ & $64.010 \mathrm{a} \pm 0.172$ \\
\hline \multicolumn{3}{c}{ *Date of sampling } \\
\hline April & $28.06 \mathrm{a} \pm 6.250$ & $64.085 \mathrm{~b} \pm 0.181$ \\
May & $20.36 \mathrm{~b} \pm 1.495$ & $64.463 \mathrm{a} \pm 0.129$ \\
September & $3.27 \mathrm{c} \pm 1.762$ & $63.196 \mathrm{c} \pm 0.068$ \\
\hline \multicolumn{3}{c}{ Bearing status } \\
\hline **ON & $17.00 \mathrm{a} \pm 3.139$ & $63.799 \mathrm{a} \pm 0.155$ \\
OFF & $17.46 \mathrm{a} \pm 4.929$ & $64.030 \mathrm{a} \pm 0.175$ \\
\hline
\end{tabular}

* Different dates representative of 10 days after leaf appearance (April), 23 days after full bloom = fruit setting (May) and 125 days after full bloom $=$ color change of fruit (September).

**ON means fruit bearing trees, OFF means non-bearer trees. In each column data presented as means $\pm \mathrm{SE}$
Flowers of barberry are formed on one-yearold shoots, so, some annual new shoots growth is needed for next season yielding. We observed that in the ON years, a very poor or no vegetative shoot flush is produced, which may in the next year reduce number of flowers and fruit production as well. On the other hand, in the next season (OFF year), a strong vegetative growth flush was observed, often longer than $1 \mathrm{~m}$ per shoot. The number of leaves per node on each shoot is also 3 or 4 , and the highest value was observed in Zohan location. Final berry numbers per inflorescence for all locations showed significant differences, and the highest number was obtained in Zohan location. The ratio of leaf number to berry number per inflorescence showed low values for all locations except Amirabad (Table 2). In this plant, lateral mixed buds located on one-yearold shoots started to create both leaves and inflorescences as vegetative and reproductive organs, respectively. It means that lower berry number per inflorescence together with more days of PRFP resulted in lower ABI value. Stevenson and Shackel (1998) working on pistachio suggested that continued high production each year should be physiologically possible if alternate bearing is not the result of limited carbohydrate availability. We suggest that a strong competition for carbohydrates between fruits and vegetative growth in barberry leads to no vegetative flush. Martínez-Alcántara et al. (2015) working on alternate bearing in citrus showed that OFF trees have stronger shoot growth compared with $\mathrm{ON}$ trees, and fruits compete for carbon with shoots. ABI value significantly increased with age increment, and a positive correlation $\left(\mathrm{R}^{2}=0.78\right)$ was observed between these factors (data not shown). 
Table 4. The interaction of location $\times$ sampling date and bearing $\times$ sampling date on shoot carbohydrates content $\left(\mathrm{mg} \cdot \mathrm{g}^{-1} \mathrm{DM}\right)$

\begin{tabular}{lrrrc}
\hline \multirow{2}{*}{ Date of sampling } & \multicolumn{2}{c}{ Location } & \multicolumn{2}{c}{ Bearing status } \\
\cline { 2 - 5 } & \multicolumn{1}{c}{ Amirabad } & Marak & \multicolumn{1}{c}{ ON } & OFF \\
\hline April & $19.72 \mathrm{~b} \pm 0.724$ & $36.41 \mathrm{a} \pm 11.98$ & $24.88 \mathrm{~b} \pm 4.915$ & $31.25 \mathrm{a} \pm 11.987$ \\
May & $18.98 \mathrm{c} \pm 1.703$ & $21.73 \mathrm{~b} \pm 2.485$ & $21.47 \mathrm{c} \pm 2.659$ & $19.24 \mathrm{~d} \pm 1.506$ \\
September & $1.19 \mathrm{e} \pm 1.716$ & $5.34 \mathrm{~d} \pm 2.567$ & $4.65 \mathrm{e} \pm 3.165$ & $1.88 \mathrm{f} \pm 1.778$ \\
\hline
\end{tabular}

For explanation see Table 3. In each column data presented as means $\pm \mathrm{SE}$

Table 5. The interaction of location $\times$ sampling date $\times$ bearing status on the shoot carbohydrates content $\left(\mathrm{mg} \cdot \mathrm{g}^{-1} \mathrm{DM}\right)$

\begin{tabular}{llcc}
\hline \multirow{2}{*}{ Location } & Date of & \multicolumn{2}{c}{ Bearing status } \\
\cline { 2 - 4 } & sampling & \multicolumn{1}{c}{ ON } & OFF \\
\hline \multirow{3}{*}{ Amira- } & April & $20.30 \mathrm{~d} \pm 0.969$ & $19.13 \mathrm{~d} \pm 1.160$ \\
bad & May & $19.28 \mathrm{~d} \pm 2.282$ & $18.68 \mathrm{~d} \pm 3.034$ \\
& Septem- & $0.68 \mathrm{f} \pm 1.938$ & $1.69 \mathrm{f} \pm 2.644$ \\
& ber & & \\
\hline \multirow{3}{*}{ Marak } & April & $29.46 \mathrm{~b} \pm 9.944$ & $43.37 \mathrm{a} \pm 23.881$ \\
& May & $23.65 \mathrm{c} \pm 5.036$ & $19.81 \mathrm{~d} \pm 1.349$ \\
& Septem- & $8.61 \mathrm{e} \pm 2.546$ & $2.07 \mathrm{f} \pm 2.967$ \\
\hline
\end{tabular}

For explanation see Table 3. In each column data presented as means $\pm \mathrm{SE}$

Table 6. Single effect of location, sampling date and bearing on total carbohydrates and phenolics contents in leaves

\begin{tabular}{lcc}
\hline & $\begin{array}{c}\text { Carbohydrate } \\
\left(\mathrm{mg} \cdot \mathrm{g}^{-1} \mathrm{DM}\right)\end{array}$ & $\begin{array}{c}\text { Total phenolic } \\
\left(\mathrm{mg} \text { gallic acid } \cdot \mathrm{g}^{-1} \mathrm{DM}\right)\end{array}$ \\
\cline { 2 - 3 } & \multicolumn{2}{c}{ Location } \\
\hline Amirabad & $21.34 \mathrm{~b} \pm 3.090$ & $64.59 \mathrm{a} \pm 0.202$ \\
Marak & $33.88 \mathrm{a} \pm 9.688$ & $64.66 \mathrm{a} \pm 0.216$ \\
\hline \multicolumn{3}{c}{ *Date } \\
\hline April & $23.79 \mathrm{~b} \pm 2.143$ & $64.91 \mathrm{a} \pm 0.250$ \\
May & $50.29 \mathrm{a} \pm 12.606$ & $65.15 \mathrm{a} \pm 0.192$ \\
September & $8.76 \mathrm{c} \pm 2.426$ & $63.82 \mathrm{~b} \pm 0.113$ \\
\hline \multicolumn{3}{c}{ Bearing status } \\
\hline OFF & $21.52 \mathrm{~b} \pm 0.155$ & $64.67 \mathrm{a} \pm 0.226$ \\
ON & $33.71 \mathrm{a} \pm 0.175$ & $64.58 \mathrm{a} \pm 0.190$ \\
\hline
\end{tabular}

For explanation see Table 3. In each column data presented as means $\pm \mathrm{SE}$

However, ABI value was similar for shrubs aged between 20 and 50 years. Shrubs aged less than 20 years showed the lowest $A B I$ value and those $\geq 50$ years the highest (Fig. 1), which was in agreement with the findings of Crane and Forde (1976) and
Sparks (1975) on pecan and in disagreement with Jonkers (1979) on apple. Crane and Forde (1976) and Sparks (1975) suggested higher value for the ratio of leaves to fruits and flowers in younger trees than in elders.

Experiment 2. Evaluation of total carbohydrates showed a significant change in this variable because of the location; however, the level of phenolics compounds in vegetative organs was unaffected. Sampling dates showed the highest content of carbohydrates 10 days after leaf appearance, which decreased at 23 day after full bloom and then a dramatic reduction in September. Regarding to phenolics contents, vegetative organs showed a small differences in this variable during three sampling dates (Tables $3 \& 4$ ). The analysis of data showed a reducing trend in total carbohydrates content of both ON and OFF shrubs in September; however, the highest value was indicated in fruit-bearing shrubs in April sampling (Tables $5 \& 6$ ). It is suggested that in the ON shrubs, fruit setting needs large amounts of carbohydrates. Strong vegetative growth on OFF plants also needs large amounts of carbohydrates, so, depletion of carbohydrates occurs. Higher concentration of total carbohydrates occurring early in the season was in agreement with findings of Nzima et al. (1997) on pistachio. The interaction of location $\times$ sampling $\times$ bearing showed the lowest value of this variable in September, without regarding to the location and ON and OFF statuses for both organs (Tables $7 \& 8$ ). Moreover, data showed large carbohydrates pools in leaves of $\mathrm{ON}$ shrubs during May, contrary to OFF shrubs, in which a reducing trend occurred in May (Table 8), which may be resulted from strong vegetative leaf growth in early season. However, the highest shoot carbohydrates content in the ON shrubs was obtained in samplings of April and May, which was reduced in final samplings (Table 7). 
Table 7. The interaction of location $\times$ sampling date and bearing status $\times$ sampling date on leaf carbohydrates content $\left(\mathrm{mg} \cdot \mathrm{g}^{-1} \mathrm{DM}\right)$

\begin{tabular}{lcccc}
\hline \multirow{2}{*}{ Date of sampling } & \multicolumn{2}{c}{ Location } & \multicolumn{2}{c}{ Bearing status } \\
\cline { 2 - 5 } & Amirabad & Marak & ON & OFF \\
\hline April & $23.86 \mathrm{c} \pm 2.750$ & $23.71 \mathrm{c} \pm 3.555$ & $18.29 \mathrm{c} \pm 1.747$ & $29.29 \mathrm{~b} \pm 2.325$ \\
May & $31.63 \mathrm{~b} \pm 5.473$ & $68.95 \mathrm{a} \pm 23.283$ & $76.07 \mathrm{a} \pm 21.103$ & $24.50 \mathrm{~b} \pm 2.195$ \\
September & $8.54 \mathrm{~d} \pm 2.160$ & $8.99 \mathrm{~d} \pm 4.596$ & $6.76 \mathrm{~d} \pm 3.376$ & $10.76 \mathrm{~d} \pm 3.393$ \\
\hline
\end{tabular}

For explanation see Table 3.

Table 8 . The interaction of location $\times$ bearing status on leaf carbohydrates content $\left(\mathrm{mg} \cdot \mathrm{g}^{-1} \mathrm{DM}\right)$

\begin{tabular}{lcc}
\hline \multirow{2}{*}{ Location } & \multicolumn{2}{c}{ Bearing status } \\
\cline { 2 - 3 } & \multicolumn{1}{c}{ ON } & OFF \\
\hline Amirabad & $23.00 \mathrm{~b} \pm 5.185$ & $19.68 \mathrm{~b} \pm 3.606$ \\
Marak & $44.41 \mathrm{a} \pm 19.119$ & $23.35 \mathrm{~b} \pm 3.259$ \\
\hline
\end{tabular}

Data presented as means $\pm \mathrm{SE}$.
Table 9. The interaction of location $\times$ sampling date $\times$ bearing status on the leaf carbohydrates content $\left(\mathrm{mg} \cdot \mathrm{g}^{-1} \mathrm{DM}\right)$

\begin{tabular}{|c|c|c|c|}
\hline \multirow{2}{*}{ Location } & \multirow{2}{*}{ Date } & \multicolumn{2}{|c|}{ Bearing status } \\
\hline & & $\mathrm{ON}$ & OFF \\
\hline \multirow{3}{*}{ Amirabad } & April & $19.39 \mathrm{~d} \pm 1.100$ & $28.33 \mathrm{c} \pm 4.081$ \\
\hline & May & $40.16 b \pm 7.848$ & $23.09 \mathrm{~d} \pm 3.912$ \\
\hline & September & $9.44 \mathrm{e} \pm 3.759$ & $7.63 \mathrm{e} \pm 2.897$ \\
\hline \multirow{3}{*}{ Marak } & April & $17.18 \mathrm{~d} \pm 3.629$ & $30.25 c \pm 3.076$ \\
\hline & May & $111.99 \mathrm{a} \pm 31.504$ & $25.92 \mathrm{c} \pm 2.609$ \\
\hline & September & $4.08 \mathrm{f} \pm 5.067$ & $13.89 \mathrm{e} \pm 2.275$ \\
\hline
\end{tabular}

For explanation see Table 3.

Table 10. Analysis of variance for total carbohydrates and phenolics contents in vegetative organs

\begin{tabular}{lcrc}
\hline \multirow{2}{*}{ Source of variation } & & \multicolumn{2}{c}{ Mean Square } \\
\cline { 3 - 4 } & DF & total carbohydrates & Leaves \\
\cline { 3 - 4 } Block & 2 & 13.11 & 0.0113 \\
Location & 1 & 1415.58 & 0.0399 \\
Date of sampling & 2 & 5304.87 & 5.9876 \\
Bearing status & 1 & 1337.27 & 0.0713 \\
Location $\times$ date & 2 & 1382.23 & 0.3806 \\
Location $\times$ bearing & 1 & 708.50 & 0.6952 \\
Date $\times$ bearing & 2 & 3526.59 & 0.5995 \\
Location $\times$ date $\times$ bearing & 2 & 1487.93 & 0.4286 \\
Residual & 22 & 16.60 & 0.5134 \\
Total & 35 & & \\
\hline & & & \\
\hline Block & 2 & 3.243 & 0.3571 \\
Location & 1 & 557.223 & 0.3242 \\
Date of sampling & 2 & 1932.996 & 5.0831 \\
Bearing status & 1 & 1.911 & 0.4818 \\
Location $\times$ date & 2 & 176.894 & 0.0379 \\
Location $\times$ bearing & 1 & 4.575 & 0.0388 \\
Date $\times$ bearing & 2 & 78.789 & 0.3702 \\
Location $\times$ date $\times$ bearing & 2 & 108.320 & 0.0599 \\
Residual & 22 & 3.217 & 0.2117 \\
Total & 35 & & \\
\hline & & & \\
\hline
\end{tabular}


About OFF shrubs, similar results were obtained during sampling of leaves in April and May (Table 7). It is believed that leaves with stronger photo assimilation activities accumulated more carbohydrates, but shoot carbohydrate pools were significantly influenced by previous season activities of photo assimilation. The ON shrubs having many fruits contain high amounts of anthocyanins, which needs many $\mathrm{C}$ skeletons for color change and for other changes associated with growth (Khayyat et al. 2018). The highest shoot carbohydrate content was observed in both locations in April, while in the leaves, it was observed in May (Tables 5 \& 6). Akao et al. (1981) stated that during flower formation and fruit setting, part of the reserves is translocated to the reproductive organs. The interaction of location $\times$ bearing on leaf carbohydrates content had less effect on OFF shrubs, but on ON shrubs, the highest content was obtained in Marak (Table 9). This location was characterized by highest altitude and greater differences between day and night temperature (Table 1). In comparison with carbohydrates, contents of total phenolics showed no variation depending on the location and ON and OFF statuses and showed less variation connected with date of sampling (Tables 3 \& 10).

\section{CONCLUSION}

Barberry plants are strong alternate bearer and show ABI of 0.63-0.71 depending on orchard location and from 0.42 to 0.69 depending on plants age what means, that in the older plants alternate bearing is strongly expressed. Moreover, short PRFP was connected with high ABI value. The highest phenolics content in vegetative organs was observed in May samplings, although it was not always significantly different. Total carbohydrates content in both ON and OFF shrubs decreased during fruit color change.

\section{REFERENCES}

Akao S., Tsukahara S., Hisada H., Ono S. 1981. Contribution of photosynthetic assimilates to development of flower and spring flush in Citrus unshiu Marc. Journal of the Japanese Society for Horticultural Science
50: 1-9. DOI: 10.2503/jjshs.50.1. [in Japanese with English abstract]

Akillioglu M. 1995. Studies on the seasonal changes of natural phenolic compounds in the olive trees. Ph.D. thesis, Ege University, Bornova, İzmir, Turkey. [in Turkish, with English abstract]

Barnett J., Mielke E.A. 1981. Alternate bearing: A reevaluation. Pecan South 8: 20-30.

Crane J.C., Forde H.I. 1976. Effects of four rootstocks on yield and quality of pistachio nuts. Journal of the American Society for Horticultural Science 101: 604-606.

Crane J.C., Nelson M.M. 1971. The unusual mechanism of alternate bearing in pistachio. HortScience 6: 489-490.

Ercan H., Özkaya M.T. 2008. The monthly change of phenolic compounds in some Turkish olive cultivars. Acta Horticulturae 791: 321-324. DOI: 10.17660/actahortic.2008.791.45.

Fahmi I. 1958. Changes in carbohydrate and nitrogen content of 'Souri' olive leaves in relation to alternate bearing. Proceedings of the American Society for Horticultural Science 78: 252-256.

Gemoets E.E., Gemoets L.A., Cannot T.E., McIntyre R.G. 1976. Cycles of U.S. pecan production, 19191974, identified by power spectral analysis. Journal of the American Society for Horticultural Science 101: 550-553.

Goldschmidt E.E. Golomb A. 1982. The carbohydrate balance of alternate-bearing citrus trees and the significance of reserves for flowering and fruiting. Journal of the American Society for Horticultural Science 107(2): 206-208.

Hoblyn T.N., Grubb N.H., Painter A.C., Wates B.L. 1936. Studies in biennial bearing. Journal of Pomology and Horticultural Science 14: 39-76. DOI: 10.1080/03683621.1937.11513464.

Irigoyen J.J., Einerich D.W., Sánchez-Díaz M. 1992. Water stress induced changes in concentrations of proline and total soluble sugars in nodulated alfalfa (Medicago sativa) plants. Physiologia Plantarum 84(1): $\quad 144-158 . \quad$ DOI: $10.1111 / j .1399$ 3054.1992.tb08764.x.

Jonkers H. 1979. Biennial bearing in apple and pear: a literature survey. Scientia Horticulturae 11: 303 317. DOI: 10.1016/0304-4238(79)90015-3.

Khayyat M., Barati Z., Aminifard M.H., Samadzadeh A. 2018. Changes in fruit maturity indices and growth pattern along the harvest season in seedless barberry under different altitude conditions. Journal of Berry Research 8: 25-40. DOI: 10.3233/jbr-170166. 
Kozlowski T.T., Keller T. 1966. Food relations of woody plants. Botanical Review 32: 293-382. DOI: 10.1007/bf02858663.

Kozlowski T.T. 1992. Carbohydrate sources and sinks in woody plants. Botanical Review 58: 107-222. DOI: $10.1007 / \mathrm{bf0} 2858600$.

Kramer P.J., Kozlowski T.T. 1979. Physiology of woody plants. Academic Press, USA, 811 p.

Lavee S. 1989. Involvement of plant regulators and endogenous growth substances in the control of alternate bearing. Acta Horticulturae 239: 311-322. DOI: $10.17660 /$ actahortic.1989.239.50.

Martínez-Alcántara B., Iglesias D.J., Reig C., Mesejo C., Agustí M., Primo-Millo E. 2015. Carbon utilization by fruit limits shoot growth in alternate-bearing citrus trees. Journal of Plant Physiology 176: 108117. DOI: 10.1016/j.jplph.2014.12.001.

Mert C., Barut E., İpek A. 2013. Quantitative seasonal changes in the leaf phenolic content related to the alternate-bearing patterns of olive (Olea europaea L. cv. Gemlik). Journal of Agricultural Science and Technology 15: 995-1006.

Monselise S.P., Goldschmidt E.E. 1982. Alternate bearing in fruit trees. Horticultural Reviews 4: 128-173. DOI: 10.1002/9781118060773.ch5.

Morettini A. 1950. Olivicultura. Trattati di agricoltura 9. Ramo Editoriale degli Agricoltori, Italy, 595 p. [in Italian]

Nzima M.D.S., Martin G.C., Nishijima C. 1997a. Seasonal changes in total nonstructural carbohydrates within branches and roots of naturally "off" and "on" 'Kerman' pistachio trees. Journal of the American Society for Horticultural Science 122: 856-862.

Nzima M.D.S., Martin G.C., Nishijima C. 1997b. Leaf development, dry matter accumulation, and distribution within branches of alternate-bearing 'Kerman' pistachio trees. Journal of the American Society for Horticultural Science 122: 31-37.

Nzima M.D.S., Martin G.C., Nishijima C. 1999. Effect of fall defoliation and spring shading on shoot carbohydrate and growth parameters among individual branches of alternate bearing 'Kerman' pistachio trees. Journal of the American Society for Horticultural Science 124: 52-60.

Oliveira C.M., Priestly C.A. 1988. Carbohydrate reserves in deciduous fruit trees. Horticultural Reviews 10: 403-430. DOI: 10.1002/9781118060834.ch10.

Poli M. 1979. Etude bibliographique de la physiologie de l'alternance de production chez l'olivier (Olea europaea L.). Fruits 34: 687-694. [in French]

Rezvani Moghaddam P., Fallahi J., Aghhavani Shajari M, Nassiri Mahallati M. 2013. Effects of harvest date, harvest time, and post-harvest management on quantitative and qualitative traits in seedless barberry (Berberis vulgaris L.). Industrial Crops and Products 42: 30-36. DOI: 10.1016/j.indcrop.2012.05.007.

Ryan D., Antolovich M., Prenzler P., Robards K., Lavee S. 2002. Biotransformation of phenolic compounds in Olea europaea L. Scientia Horticulturae 92: 147-176. DOI: 10.1016/s0304-4238(01)00287-4.

Ryan D., Prenzler P.D., Lavee S., Antolovich M., Robards K. 2003. Quantitative changes in phenolic content during physiological development of olive (Olea europaea) cultivar Hardy's Mammoth. Journal of Agricultural and Food Chemistry 51: 25322538. DOI: 10.1021/jf0261351.

Singleton V.L., Rossi J.A. Jr. 1965. Colorimetry of total phenolics with phosphomolybdic-phosphotungstic acid reagents. American Journal of Enology and Viticulture 16: 144-158.

Sparks D. 1975. The alternate fruit bearing problem in pecans. Annual Report of the Northern Nut Growers Association 65: 145-158.

Stevenson M.T., Shackel K.A. 1998. Alternate bearing in pistachio as a masting phenomenon: Construction cost of reproduction versus vegetative growth and storage. Acta Horticulturae 470: 340-348. DOI: 10.17660/actahortic.1998.470.47.

Williams M.W., Edgerton L.J. 1974. Biennial bearing of apple trees. Proceedings of the XIX International Horticultural Congress, Poland, vol. 3: 343-352.

Wood B.W. 1991. Alternate bearing of pecan. In: Wood B.W., Payne J.A. (Eds.), $1^{\text {st }}$ National Pecan Workshop Proceedings. Agriculture Research Service 96: 180-191. 